\title{
Reliability analysis of compaction characteristics of tropical black clay admixed with lime and iron ore-silica based dominant tailing
}

Paul YOHANNA

is a Lecturer in the Department of Civil Engineering, University of Jos, Nigeria. He specializes in Geotechnical and GeoEnvironmental Engineering. His current research effort is focused on sustainable and eco-friendly materials for Civil Engineering works

Roland K. ETIM

is a Lecturer in the Department of Civil Engineering, Akwa Ibom State University, Ikot Akpaden, Nigeria. His research interest is in the field of Geotechnical and Geo-Environmental Engineering as well as sustainable cleaner materials for Civil Engineering infrastructures. $\mathrm{He}$ s a member of several Professional societies.

KolAwolE J. OSINUBI - Department of Civil Engineering, Ahmadu Bello University, Zaria, Nigeria

John M. BUKI - Department of Civil Engineering, Ahmadu Bello University, Zaria, Nigeria

Érkezett: 2021. 01. 13. - Received: 13. 01. 2021. - https://doi.org/10.14382/epitoanyag-jsbcm.2022.3

\begin{abstract}
Reliability estimates of compaction characteristics of lime-iron ore tailings (IOT) modified tropical black clay (i.e black cotton soil, BCS) for use as road construction material was carried out. A model was generated from measured laboratory test results, and then used in a FORTRAN-based first-order reliability program (FORM) to generate reliability indices (RI). Samples tested in the laboratory were subjected to index tests and British standard light (BSL) compaction test. In the midst of all the variables, specific gravity (Gs) recorded the greatest significant effect followed by sand content $(\mathrm{Sa})$ and then Iron ore tailing (IOT) and Lime (Li) content on MDD. In the case of optimum moisture content (OMC), specific gravity (Gs), iron ore tailing content (IOT) and lime content (Li) has the most significant influence on OMC followed by sand content ( $\mathrm{Sa}$ ). Generally, RI values were less than 1.0 and thus fails to meet the conditions of Nordic Committee on Building Regulation (NKP) for serviceability limit state design. Stochastically, BSL compactive efforts recorded positive results but did not meet the requirement for modeling compaction characteristics of lime-IOT treated BCS as pavement sub-base material. Finally, higher compactive effort is recommended to model compaction characteristics of lime-IOT treated BCS in other to achieve more effective RI which that can be prudently examined during field compaction.

Keywords: reliability index, reliability analysis, tropical black clay, lime, iron ore tailings, compaction characteristics

Kulcsszavak: megbízhatósági index, megbízhatósági elemzés, trópusi fekete agyag, mész, vasérc zagy, tömörítési jellemzôk
\end{abstract}

\section{Introduction}

The overall performance of a designed engineering infrastructure depends on the magnitude of induced load as well as the mechanical strength and stiffness. Köhler [1] reported that this performance is a function of the factor of safety or reliability of structural component against failure. In other words, failure due to collapse or deflection or any other mode that may result to consequential damages in cost, loss of lives and over bearing influence to the environment are of interest [1].

The design of any engineering structure should ultimately meet the safety requirement without compromising basic condition of functionality, aesthetics and cost or economy value [2]. When an engineering structure bears a load, the expected reaction is dependent on load magnitude, load type and the structural stiffness and strength. The response of an engineering structure to loading should be considered satisfactory relative to how well it meets safety requirement [3].

Recent researches in modern times have applied the technique of reliability estimation in evaluating diverse engineering functions [4-7]. The results recorded some innovative approach which has shown varieties of far reaching outcome [8]. Before the advent of optimization by reliability approach, inspection of structural members and subsequent approval for maintenance activities were exclusively centred on past engineering evaluations, experiences and judgement. Also, probability theory and functions in which random statistical variables such as coefficient of variations (COV), mean values and standard deviations were use has presented increasing success in a broad scope of engineering designs and applications [9].

It has been reported by Oriola and Moses [10] that expansive soils referred to as "black cotton soil (BCS)" in some world regions exhibit some form of undesired engineering characteristics. Most expansive soils have varying colours that could be either light to dark grey. BCS are found in tropical and temperate zones of the semi-arid regions where the rate of annual evaporation surpasses the rainfall $[11,12]$. Black cotton soils cover an approximated land area of about $104 \times 10^{3} \mathrm{~km}^{2}$ in Northeastern Nigeria [13]. Montmorillonite clay mineral in BCS is responsible for the unprecedented rate of swell or shrink during wet and dry seasons, respectively [14].

The probabilistic based methods of measuring uncertainties in structural engineering [15-18], pavement design [19- 
22] and geotechnical engineering [23-25], has been largely successful. The First Order Reliability Method (FORM) integrated in FORTRAN program was employed to measure the suitability of BCS-Li-IOT admixtures as sub-base structure in road construction. This research is centred on developing a procedure that could be useful in estimating the structural RI for the stabilization potential of Li-IOT-BCS blend as road subbase materials. The objectives of the study are but not limited to evaluating the influence of admixtures (lime and iron ore tailing), particle sizes (gravel, sand and fine content), specific gravity as well as COV on RI for BCS using BSL compaction energy.

\section{Theoretical background of reliability index}

The factor of safety i.e., reliability or safety index, $\beta$ is an important parameter used in appraising the competence of engineering design. The safety index is a function of the ratio between the mean and standard deviation of the safety margin of the system expressed as;

$\beta=\frac{\mu}{d}$

where $\beta=$ the safety index or reliability index, $\mu=$ the mean value of the safety margin and $\mathrm{d}=$ the standard deviation. Alternatively, it is expressed as the number of standard deviation $\mathrm{dx}$ between the mean of the safety margin.

$E(s)=\mu$

Also, critical value expressed as $S=0$

Also, the RI also expressed as $\beta$ is the inverse of the COV of the safety margin $(\mathrm{COV})_{s}[26]$, that is

$\beta=\frac{1}{(\mathrm{COV})_{s}}$

The principle of First Order Reliability Method (FORM) is based on the probabilistic and deterministic approaches of design which differ in principle as applied in different engineering uses. The deterministic optimization design approach is based on design which is constrained to the design limit with no room for uncertainties i.e the likelihood of failure is completely eliminated $[4,7,27]$. Probabilistic design measure of a pavement or structure is concerned with the certainty or probability of assurance that is able to realize the postconstruction functions associated or assigned to it [28]. This functions are unconnected with basic engineering properties characterised for the purpose which in the case of a sub-base pavement are compaction behaviour, index properties and ultimately the CBR $[27,29]$. In order to study the effect of the variables on the system performance, a limit state equation (LSE) in relations to the design variable is mandatory [28]. This LSE is stated as performance function and is defined as:

$G(t)=G\left(X_{1} X_{2} X_{3} X_{n}\right)$

Where $X_{I}$ for $I=1,2,3, \ldots \ldots \ldots . n$, denote the basic design variables. The system limit state is thus defined as

$G(t)=0$

It has been reported by Duncan [30] that reliability computations require a process of assessing the joint effects of unlikelihood and also a way of differentiating between circumstances where indecision varies. Probabilistic concept of reliability analysis is suitable for evaluating the uncertainties that is involved in the choice of value for a soil variable in geotechnical analysis [30]. If the mean, variance, standard deviation etc associated with the distribution of a probability function for $\mathrm{K}$ are established, then the soil reliability can be evaluated from Eq. (7). The potential of Eq. (7) is possible only with the probability of survival as given in Eq. (8):

$P_{S}=1-P_{f}$

Where $\mathrm{P}_{\mathrm{s}}=$ probability of survival and $\mathrm{P}_{\mathrm{f}}=$ probability of failure. The probability of failure (Pf) can then be formulated as:

$P_{f}=P\left(K_{0}-K_{e}(L i, I O T, S a, F\right.$ and $\left.G s)<0\right)$

where: Ke and Ko are expected compaction properties (MDD and OMC) and compaction properties (MDD and OMC) of untreated soil, respectively. The probability of failure depends absolutely on the Lime (Li), IOT (iron ore tailing), Sa (sand), and Fine $(F)$ content and specific gravity, $\left(G_{s}\right)$

\section{Materials and methods}

The clay sample was sourced from Dandin Kowa which is $30 \mathrm{~km}$ from Gombe town in Gombe State, Nigeria. Iron oresilica based tailing waste was procured from a mining site in Itakpe, Nigeria. Lime $(\mathrm{Li})$ was sourced from an open market in Kaduna State. The composition of tailing and lime used had been reported in [33]. The database results used for this analysis were extracted from analysis of laboratory experiments of an unpublished work [31] on Li-IOT modification of BCS. The statistical properties of the compositional and compaction variables for the Li-IOT treated soil are given Table 1. A conceptual regression models (as shown in Eq. 9 and 10) were developed for predicting MDD and OMC. The Mini-tab R15 statistical software tool was used to establish the basic statistics for the various compositional variables/constraints. The potentials of Li-IOT combination on the compaction parameters (MDD and OMC) of BCS was assessed using first order reliability methods' version 5.0 (FORM 5) written in FORTRAN language. The statistical properties of the various compositional variables (MDD and OMC), Li, IOT, Gr, Sa, F content and Gs) as well as their probability distribution functions forms were conventionally proven and well established. The various statistical properties (mean, standard deviations and coefficient of variations) for Li-IOT mixtures were then integrated into a FORTRAN based program for a field based predictive model. Response to sensitivity study for each of the independent variables, their impact on compaction characteristics was accomplished by varying the assumed values of COV ranging from $10-100 \%$ in step of $10 \%$ to obtain reliability/safety indices or $\beta$-values. The $\beta$-values for the dependent (MDD and OMC) and independent ( $\mathrm{Li}, \mathrm{IOT}, \mathrm{Gr}$, $\mathrm{Sa}, \mathrm{F}$ content and Gs) variables were evaluated.
$\mathrm{MDD}=2.475-0.0105 \mathrm{Li}+0.00831 \mathrm{IOT}-0.0086 \mathrm{Gr}+$
$0.00 \mathrm{Sa}-0.0046 \mathrm{~F}+5.415 \mathrm{Gs}$
(9) $R^{2}=91.4$
$\mathrm{OMC}=32.684+0.2498 \mathrm{Li}-0.1722 \mathrm{IOT}-0.146 \mathrm{Gr}+$
$0.00 \mathrm{Sa}-0.0133 \mathrm{~F}-3.461 \mathrm{Gs}$
(10) $R^{2}=89.8$ 


\begin{tabular}{|c|c|c|c|c|c|}
\hline S/No & Variables & $\begin{array}{c}\text { Distribution } \\
\text { type }\end{array}$ & $\begin{array}{l}\text { Mean } \\
E(x)\end{array}$ & $\begin{array}{l}\text { Standard } \\
\text { deviation } \\
\mathbf{S}(\mathbf{x})\end{array}$ & $\begin{array}{l}\text { Coefficient } \\
\text { of Variation } \\
\text { COV (\%) }\end{array}$ \\
\hline 1 & $\begin{array}{l}\text { Maximum dry } \\
\text { density }\end{array}$ & Lognormal & 15.77 & 0.28 & 56.32 \\
\hline 2 & $\begin{array}{c}\text { Optimum } \\
\text { moisture } \\
\text { content }\end{array}$ & Lognormal & 22.42 & 0.92 & 24.37 \\
\hline 3 & Lime content & Normal & 2.00 & 1.44 & 1.39 \\
\hline 4 & $\begin{array}{l}\text { Iron ore tail- } \\
\text { ings content }\end{array}$ & Normal & 5.00 & 3.47 & 1.44 \\
\hline 5 & $\begin{array}{c}\text { Gravel con- } \\
\text { tent }\end{array}$ & Normal & 1.05 & 0.93 & 1.13 \\
\hline 6 & Sand content & Normal & 21.29 & 4.04 & 5.27 \\
\hline 7 & Fine Content & Normal & 77.66 & 4.07 & 19.08 \\
\hline 8 & $\begin{array}{l}\text { Specific } \\
\text { gravity }\end{array}$ & Normal & 2.52 & 0.04 & 63.00 \\
\hline Table 1 & \multicolumn{5}{|c|}{$\begin{array}{l}1 \text { Compositional parameters from laboratory measured compaction } \\
\text { characteristics for reliability based design for seven independent variables } \\
\text { using FORM } 5\end{array}$} \\
\hline 1. táblázat & \multicolumn{5}{|c|}{$\begin{array}{l}\text { A kompozíciós paraméterek laboratóriumban mért tömöritési jellemzökböl } \\
\text { a megbizhatóság alapú tervezéshez (hét független változó a FORM } 5 \\
\text { szoftverhez) }\end{array}$} \\
\hline
\end{tabular}

\section{Results and discussions}

\subsection{Effect of lime and iron ore tailing on compaction characteristics}

It is obvious that the results from the conceptual model revealed a robust connection between soil dependent variable (MDD) and the soil independent variables (Li, IOT, Gr, Sa, F content and Gs) with correlation coefficient $\mathrm{R}=0.914$ (see Eq. 9). Multiple regression analysis revealed that the MDD was much more influenced by IOT content and Gs with higher values of positive coefficients. The indication from this study suggests that the higher positive coefficients could be ascribed to the higher Gs value of IOT (3.29) replacing the soil particles with lower Gs (2.47). This finding is in agreement with Sani et al., [6] which showed that Gs provide a valid parameter and was used jointly with other variables for developing a predictive model for MDD. The possible explanation to the negative coefficient of lime content in the regression model (see Eq. 9) may be linked to lower specific of lime (2.14) when related to that of the natural soil (2.47) thereafter causing a reduction in the MDD values. This implies that lime has little impact on the MDD and care need be taken to certify that an optimum blend is used in the course of field compaction of BCS- limeIOT mixtures. Similarly, a strong relationship was expressed by the multiple regression model between soil OMC (dependent variable) and soil multiple independent variables ( $\mathrm{Li}, \mathrm{IOT}, \mathrm{Gr}$, Sa, F content and Gs), with correlation coefficient $\mathrm{R}=0.898$ (see Eq. 10). Results showed that the OMC was much more influenced by lime content and specific gravity with higher coefficients. This implies that lime has positive impact on the optimum moisture content and control of admixtures content should be adequately supervised to guarantee optimum blend of lime is used in the course of field compaction of BCS- limeIOT mixtures.
4.2 Comparison between measured and predicted values of regression model

Results of laboratory estimates of MDD showed a strong relationship with its predicted estimates, and having coefficient of correlation $\mathrm{R}=0.963$ (see Fig. 1). In the case of OMC, results showed a strong relationship between the measured OMC attained in the laboratory and the predicted results achieved with the model having correlation coefficient $\mathrm{R}=0.950$ (see Fig. 2). Findings from the models suggest that the correlation coefficient values validate the combined effect of the various parameters (independent variables) in predicting MDD and OMC. This point toward the fact that specification during field compaction and control can easily be checked by a good measure of moisture that will yield an adequate dry density. This could simply be controlled using those variables in field application.

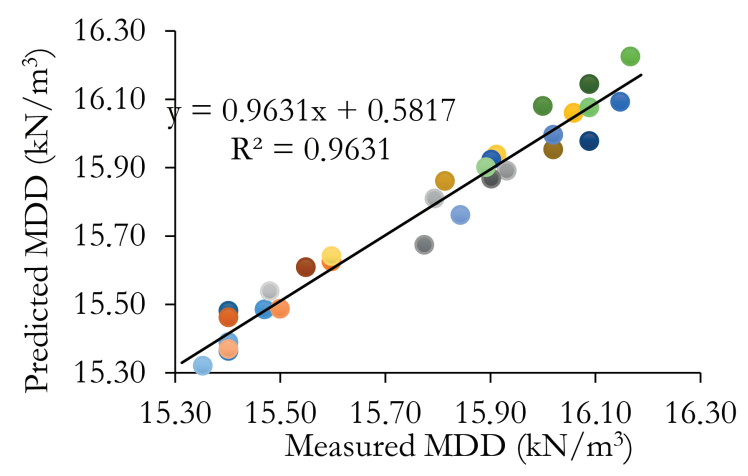

Fig. 1 Predicted $M D D$ versus measured MDD values for the various $L i-I O T-B C S$ mixtures

1. ábra A becsült MDD értéke a mért $M D D$ értékek függvényében a különbözö $\mathrm{Li}$ IOT-BCS keverékeknél

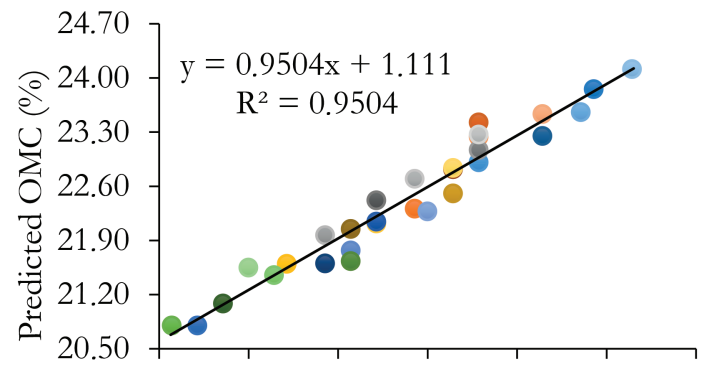

$20.5021 .2021 .90 \quad 22.6023 .3024 .00 \quad 24.70$

Measured OMC $(\%)$

Fig. 2 Predicted OMC versus measured OMC values for the various Li-IOT-BCS mixtures

2. ábra A becsült OMC értéke a mért OMC értékek függvényében a különböző LiIOT-BCS keverékeknél

\subsection{Reliability estimate on compaction characteristics}

\subsubsection{Effect of MDD and OMC on reliability index}

The effect of MDD and OMC on RI as the COV is varied is shown in Fig. 3. MDD yielded a linear but declining trend as the COV increased in step of $10 \%$ from 10 to $100 \%$. Consuently, as COV increased from 10 to $100 \%$, RI reduced from -0.16 to -0.436 . When MDD value of $15.47 \mathrm{kN} / \mathrm{m}^{3}$ for the unmodified soil was used, the RI value reduced from -0.459 to -0.401 . Comparatively, the Li-IOT modified soil recorded higher RI values than the unmodified (natural soil). These observations 
indicate that there is a far reaching enhancement on the MDD of the soil mixed with lime-IOT blends. Basically, the significant alteration in RI is sign that compaction properties could have a far-reaching influence on the RI for a sub-base material of road pavement. For OMC, RI decreased linearly from -0.365 to -0.456 . Similarly, when RI was computed with OMC value of $23 \%$ for the unmodified BCS, the value dropped linearly from -0.121 to -0.425 . Comparatively, lower RI values $(-0.365$ to $-0.456)$ were documented for the Li-IOT treated BCS soil than the natural BCS (-0.121 to -0.425). These observations indicate that there is no significant improvement on the OMC of the soil with increased in Li-IOT blends.

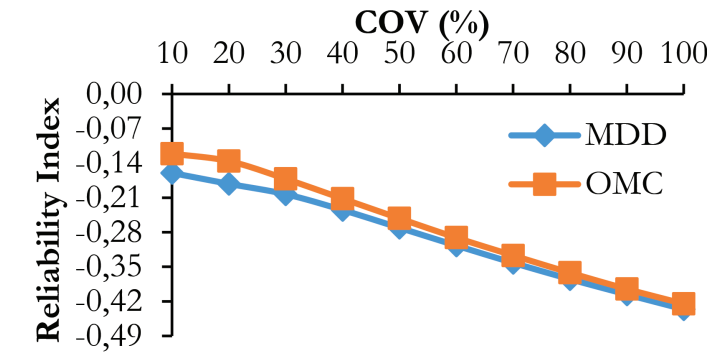

Fig. 3 Relationship between reliability index and COV for compaction characteristics

3. ábra A megbizhatósági index és a COV közötti összefüggés a tömörítési jellemzőkhöz

\subsubsection{Effect of lime content on reliability index of} compaction characteristics

Changes in RI for lime content of Li-IOT treated soil with $\mathrm{COV}$ is displayed in Fig. 4. The RI marginally increased from -0.723 to -0.722 and -0.693 to -0.634 for MDD and OMC, in that order. This show that lime content is a parameter which should be cautiously controlled in soil improvement using LiIOT. When estimated with unmodified soil of MDD and OMC value of $15.47 \mathrm{kN} / \mathrm{m}^{3}$ and $23 \%$, in that order; the RI ranged from -1.53 to -1.53 and -0.175 to -0.16 for MDD and OMC, in that order. It is evident that lime has no drastic effect on MDD since no reasonable variation in RI was observed for MDD of the untreated soil.

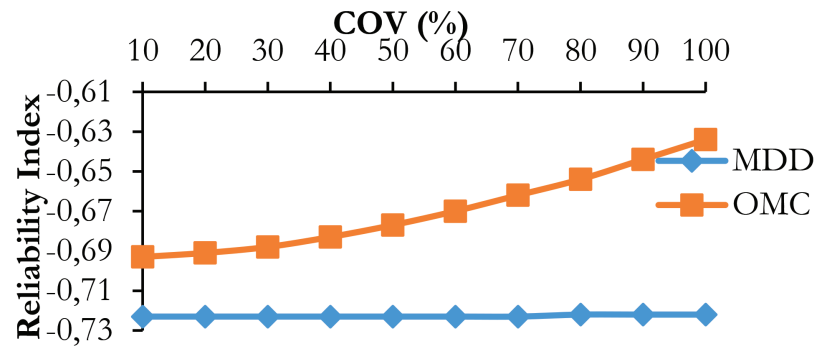

Fig. 4 Relationship between reliability index and COV for lime content 4. ábra A megbizhatósági index és a COV közötti összefüggés a mész tartalomhoz

\subsubsection{Effect of IOT content on reliability index of compaction characteristics}

The change in RI for IOT content of Li-IOT treated soil with COV (i.e 10-100\%) is revealed in Fig. 5. The RI ranged from -0.723 to -0.722 and -0.763 to -0.587 for MDD and OMC in that order. This suggest that iron ore tailing content is a parameter which need to be prudently supervised all through field compaction for Li-IOT modified BCS. Also, a comparison of the two results (treated and untreated) for MDD reveals that a higher safety value for MDD of the treated soil $(-0.723$ to $-0.723)$ is greater than the untreated soil $(-1.53$ to -1.52$)$. This simply suggest that IOT has tremendous effect on the MDD safety values of Li-IOT-BCS (treated) materials for sub-base of road pavement in contrast to the MDD of the untreated (natural BCS). Also, high IOT content could well shoot up the specific gravity of the Li-IOT-BCS mixtures [32-33], which may have contributed to the increased reliability values of MDD of treated soil. This condition could also mean that adequate ground solidification would be achieved in the long run, typically after complete long term lime reaction within the entire matrix. Interestingly, the RI for OMC of treated soil $(-0.763$ to -0.587$)$ is comparatively lower than the safety value of the natural soil (0.193 to -0.147$)$. This might not be unconnected with the non-plastic attribute of IOT [32-33], which suggest that IOT could be independent of moisture content in Li-IOT-BCS matrix.

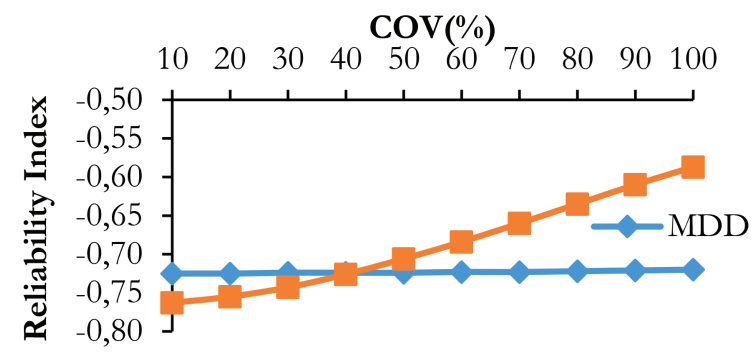

Fig. 5 Relationship between reliability index and COV for IOT content

5. ábra A megbizhatósági index és a COV közötti összefüggés az IOT tartalomhoz

\subsubsection{Effect of gravel content on reliability index of} compaction characteristics

As the COV rise from 10 to $100 \%$, the RI of MDD and OMC was slightly varied due to the effect gravel content (see Fig. 6). It can be noticed that gravel content has little or no effect on MDD and OMC as their safety value remained constant even as the COV increased from $10-100 \%$. A steady safety values of -0.723 and -0.661 were estimated for MDD and OMC respectively. Also, the computed RI values of unmodified soil remain almost constant between -1.53 and -0.167 for MDD $\left(15.47 \mathrm{kN} / \mathrm{m}^{3}\right)$ and OMC (23\%) value, respectively. While RI remained almost constant for both treated and untreated soil, a comparison of the two results (treated and untreated) reveals that a higher safety value for MDD of the treated soil $(-0.723)$ is greater than the untreated soil (-1.53). This simply suggests that gravel content has tremendous effect on the MDD safety values of Li-IOT-BCS materials for sub-base of road pavement. Also, Higher MDD and as well its safety value indicates adequate ground solidification. Regardless of the reliability values, it could be said that the effect of gravel content was visible because of the considerable effect on regulating the quantity of admixtures. Interestingly, the RI for OMC of treated soil $(-0.661)$ is relatively lower than the safety value of the natural soil $(-0.167)$. This suggests that gravel content do not have much effect on OMC of Li-IOT stabilized BCS. 


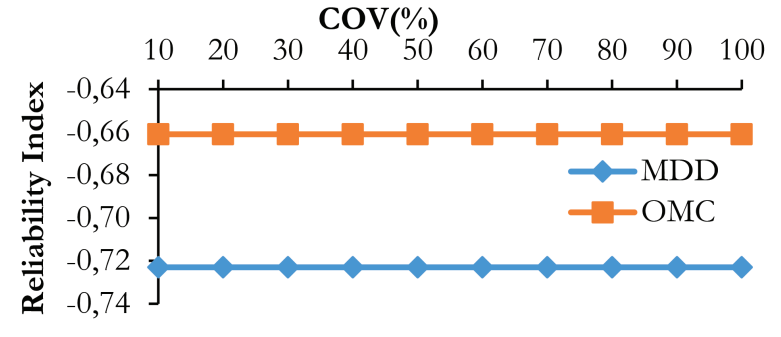

Fig. 6 Relationship between reliability index and COV for gravel content

6. ábra A megbizhatósági index és a COV közötti összefüggés a kavics tartalomhoz

\subsubsection{Effect of sand content on reliability index of compaction characteristics}

Sand content produced a slightly varied RI value for MDD and OMC with COV in the range 10 to $100 \%$ (see Fig. 7). As COV rise from 10 to $100 \%$, RI value also increased from -0.723 to -0.699 and -0.661 to -0.643 for MDD and OMC in that order. The safety values of untreated soil ranged from -1.53 to -1.48 and -0.167 to -0.162 when reliability was estimated with natural MDD $\left(15.47 \mathrm{kN} / \mathrm{m}^{3}\right)$ and OMC (23\%), respectively. Comparing the two results (treated and untreated), it can be seen that the safety value for MDD of the treated soil $(-0.723$ to -0.699$)$ is greater than unmodified soil $(-1.53$ to -1.48$)$. This simply suggest that sand content has huge effect on the treated soil and could enhance the MDD as well as its safety values in assessing the potential of Li-IOT-BCS in sub-base structure of road pavement. In contrast, the safety index for OMC of treated soil $(-0.661$ to -0.643$)$ is relatively lower than the safety value of the natural soil $(-0.167$ to -0.162$)$. This results which shows a need to be explicit about the reliability of treated and untreated BCS, indicate that sand content do not have effect on OMC of Li-IOT stabilized BCS.

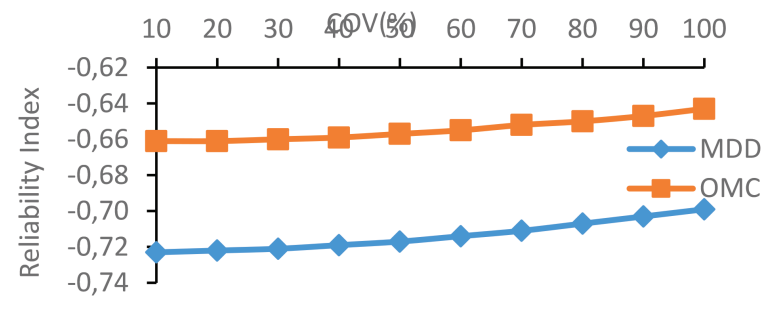

Fig. 7 Relationship between reliability index and COV for sand content

7. ábra A megbizhatósági index és a COV közötti összefüggés a homok tartalomhoz

\subsubsection{Effect of fine content on reliability index of compaction characteristics}

From Fig. 8, it can be noticed that fine content has little or no effect on MDD and OMC as their value remained almost constant when the COV increased from 10-100\%. In the case of treated soil, a continual safety index of -0.723 and -0.661 was established for MDD and OMC, in that order. When estimated with MDD and OMC value of $15.47 \mathrm{kN} / \mathrm{m}^{3}$ and $23 \%$ respectively for the untreated soil, $\beta$ value can be seen to be constant with COV (10 to $100 \%$ ) having -1.53 and -0.167 values for MDD and OMC, respectively. An assessment of the two results reveals, that the RI for MDD $(-0.723)$ of treated soil is relatively higher than the safety value of the natural soil (-1.53). The results of this research support the idea that fine content could have slight effect on reliability values that considerably varies from the treated soil to the untreated soil. In the case of $\mathrm{OMC}$, the reverse was the case. However, the zero variation of reliability index in treated and untreated, could therefore seem that fine content may have just slight effect on MDD and OMC in contrast with other variables.

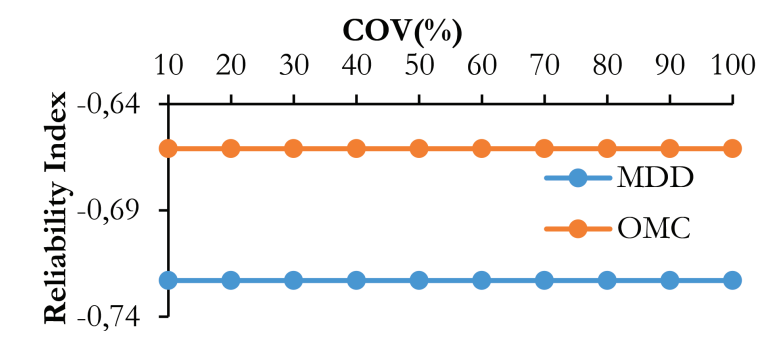

$\begin{array}{ll}\text { Fig. } 8 & \text { Relationship between reliability index and COV for fine content } \\ \text { 8. ábra } & \text { A megbízhatósági index és a COV közötti összefüggés a finomrész } \\ & \text { tartalomhoz }\end{array}$

\subsubsection{Effect of specific gravity on reliability index of} compaction characteristics

Specific gravity impact on RI as the COV increased up to $100 \%$ is presented (see Fig. 9). The RI values due to the influence of specific gravity produced a semi-linear relationship with COV stretching from 10 to $100 \%$. From the graph below, RI varied significantly. It shows that, as COV rise from 10 to $100 \%$, reliability values correspondingly increased from -0.19 to -0.0194 and -0.534 to -0.0881 for MDD and OMC, in that order. When estimated with MDD and OMC value of $15.47 \mathrm{kN} /$ $\mathrm{m}^{3}$ and $23 \%$ respectively for the unmodified soil, safety values ranged from -0.403 to -0.0411 and -0.134 to -0.0221 for MDD and $\mathrm{OMC}$, respectively. Based on this analysis, it is also worth noting that safety value of MDD for treated BCS is significantly higher than the untreated soil. This simply implies that specific gravity has major effect on the MDD safety values of Li-IOTBCS materials for construction of sub-base of road pavement. Also, higher specific gravity could translate to higher MDD as reported by [34-38]. In contrast, the RI for OMC of treated soil is relatively lower than the safety value of the natural soil. This suggests that specific gravity do not have effect on OMC of LiIOT stabilized BCS.

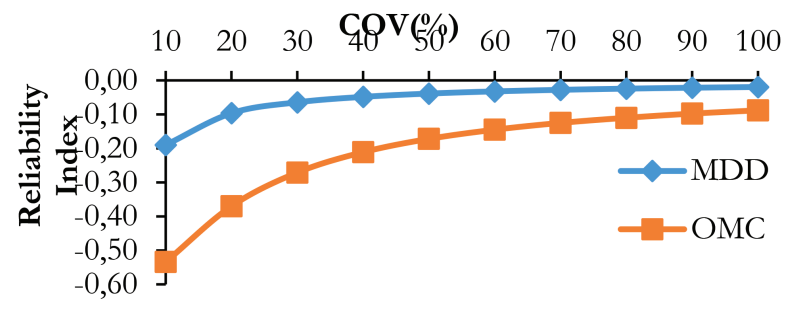

Fig. 9 Relationship between reliability index and COV for specific gravity 9. ábra A megbízhatósági index és a COV közötti összefüggés a fajsúlyhoz

\subsection{Comparison of the reliability indices of the soil compositional factors}

A comparison of the reliability index (safety index or $\beta$ value) for maximum dry density (MDD) showed some gradation of disparity in $\beta$ - value of the variables (compositional factors) considered (Fig. 10). From Fig. 10, it can be seen that the greatest 
$\beta$ - value of all the compositional factors is specific gravity (Gs) which in other words generated the highest considerable influence in contrast with sand content(Sa) followed by Iron ore tailing (IOT) and Lime(Li) content. The gravel content (Gr) and percentage fines have insignificant outcome by way of their values remaining almost unchanged at all values of 10 $100 \%$ COV input. The order of response to sensitivity analysis which can also be used to measure the influence of each of the compositional variable as they affect MDD can be represented as; Gs $>\mathrm{Sa}>\mathrm{IOT}>\mathrm{Li}>\mathrm{Gr}>\mathrm{F}$. With recourse to Fig. 11 showing the case of OMC, it can be well appreciated that the maximum range of $\beta$ - value of all the compositional properties is specific gravity (Gs) which in other words brings about the most considerable influence on OMC in contrast with IOT followed by lime (Li) and then sand (Sa). The gravel content (Gr) and percentage fines have insignificant outcome by way of their values continuing unchanged at all values of $10-100 \%$ COV input. The order of response to sensitivity analysis that measured the influence of each of the compositional variable as they affect OMC can best be represented as; Gs > IOT > $\mathrm{Li}>\mathrm{Sa}>\mathrm{Gr}>\mathrm{F}$. From the results of reliability index, it could be observed that IOT and lime content has effect on both the MDD and OMC which is also a function of the molding water content available for compaction. This could depict sensitivity of compaction characteristics to the amount of IOT and lime content of the soil. The mechanism of reaction aided by the chemical compositions of materials (BCS, lime and IOT) could also be responsible for the varying changes observed from the laboratory result thereby having effect on the sensitivity analysis. These reasons explain why; exercising caution should be paramount to achieving adequate quality control of those compositional factors. This is much needed and is absolutely important during field compaction of the soil in placement for use as embankment or as road sub-base structural materials in pavement structure. Therefore, it can be understood that the satisfactory use of Li-IOT treated BCS soil to achieve good sub-base structure for a flexible pavement is a function of numerical significance of RI values based on the existing model established from the laboratory results.

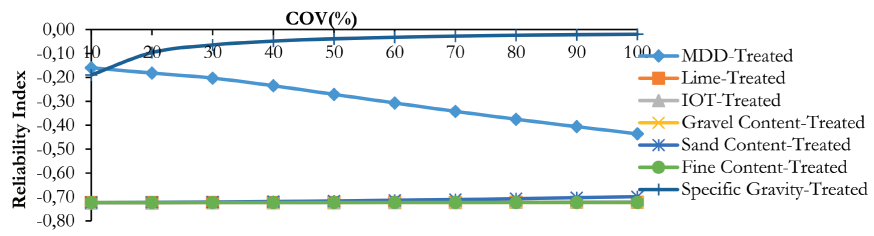

Fig. 10 RI versus COV for MDD - BSL and compositional factors of BCS - Li - IOT combination

10. ábra RI a COV függvényében az MDD - BSL-re és a BCS - Li - IOT kombináció összetételi tényezőire

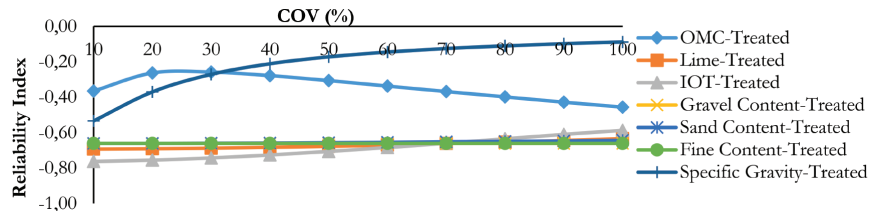

Fig. 11 RI versus COV for OMC -BSL and compositional factors of BCS - Li - IOT combinations

11. ábra RI a COV függvényében az OMC - BSL-re és a BCS - Li - IOT kombináció összetételi tényezőire

\subsection{Statistical significance of reliability indices}

The measure of statistical significance of RI on compaction parameters validate the reliability analysis that allow the study to come out with concrete decision. The decision making depends on the p-value (alpha) established. If the observed p-value is such that it is less than alpha, the outcome can be seen as statistically significant. Statistical examination of all the results acquired at $95 \%$ significant level by using the statistical F-distribution test recorded from the ANOVA test indicate that all variables have significant effect on MDD and OMC (statistical significance) (see Table 2). Therefore, all the variables should be carefully monitored as they bid direct effect on the compaction parameters (MDD and OMC).

\subsection{Stochastic model evaluation on compaction characteristics}

The evaluation of safety index was compared with the specified lowest safety index (1.0) for serviceability limit state design (Table 3). With variation in COV, it can be seen from Table 3 that the beta values for all variables were less than 1.0 which of course fall shot the lowest safety index required for serviceability limit state design [39, 40].

\begin{tabular}{lccccccc}
$\begin{array}{c}\text { Com- } \\
\text { paction } \\
\text { property }\end{array}$ & $\begin{array}{c}\text { Vari- } \\
\text { able }\end{array}$ & $\begin{array}{c}\text { Source } \\
\text { of } \\
\text { variation }\end{array}$ & $\begin{array}{c}\text { Degree } \\
\text { of } \\
\text { freedom }\end{array}$ & $\begin{array}{c}\text { F-value } \\
\text { calcu- }\end{array}$ & $\begin{array}{c}\text { P-value } \\
\text { lated }\end{array}$ & $\begin{array}{c}\text { F-value } \\
\text { critical }\end{array}$ & SS \\
\hline OMD & MDD & COV & 1 & 33.350 & $1.79 \mathrm{E}-05$ & 4.414 & SS \\
\hline MDD & Li & COV & 1 & 33.416 & $1.77 \mathrm{E}-05$ & 4.414 & SS \\
\hline OMC & & COV & 1 & 33.808 & $1.65 \mathrm{E}-05$ & 4.414 & SS \\
\hline MDD & IOT & COV & 1 & 33.873 & $1.63 \mathrm{E}-05$ & 4.414 & SS \\
\hline OMC & & COV & 1 & 33.829 & $1.65 \mathrm{E}-05$ & 4.414 & SS \\
\hline MDD & Gr & COV & 1 & 33.873 & $1.63 \mathrm{E}-05$ & 4.414 & SS \\
\hline OMC & & COV & 1 & 33.798 & $1.65 \mathrm{E}-05$ & 4.414 & SS \\
\hline MDD & Sa & COV & 1 & 33.862 & $1.64 \mathrm{E}-05$ & 4.414 & SS \\
\hline OMC & & COV & 1 & 33.790 & $1.66 \mathrm{E}-05$ & 4.414 & SS \\
\hline MDD & F & COV & 1 & 33.873 & $1.63 \mathrm{E}-05$ & 4.414 & SS \\
\hline OMC & & COV & 1 & 33.798 & $1.65 \mathrm{E}-05$ & 4.414 & SS \\
\hline MDD & Gs & COV & 1 & 33.067 & $1.89 \mathrm{E}-05$ & 4.414 & SS \\
\hline OMC & & COV & 1 & 33.254 & $1.82 \mathrm{E}-05$ & 4.414 & SS
\end{tabular}

SS $=$ statistically significant at $5 \%$

Table 2 ANOVA of reliability index values for compaction characteristics 2. táblázat A megbizhatósági index varianciaanalizisének értékei a tömöritési jellemzökre

\begin{tabular}{lcccc} 
Variable & \multicolumn{2}{c}{ Beta Value } & $\begin{array}{c}\text { Acceptable Range } \\
\text { of COV (\%) }\end{array}$ \\
MDD & -0436 to -0.16 & MDD & OMC \\
\hline OMC & - & -0.456 to -0.365 & Nil & Nil \\
\hline Li & -0.723 to-0.722 & -0.693 to -0.634 & Nil & Nil \\
\hline IOT & -0.725 to -0.72 & -0.763 to -0.587 & Nil & Nil \\
\hline Gr & -0.723 to -0.723 & -0.661 to -0.661 & Nil & Nil \\
\hline Sa & -0.723 to -0.699 & -0.661 to -0.643 & Nil & Nil \\
\hline F & -0.723 to -0.723 & -0.661 to -0.661 & Nil & Nil \\
\hline Gs & -0.19 to -0.0194 & -0.534 to -0.0881 & Nil & Nil
\end{tabular}

Table 3 Model estimation of acceptable reliability indices 3. táblázat Az elfogadható megbizhatósági indexek modellbecslése 


\section{Conclusions}

A predictive model was established from laboratory results derived from British standard light (BSL) compaction and other associated soil variables (IOT, lime, Gs, Gr, Sa, F). Estimates of compaction characteristics of compacted LiIOT treated BCS as structural sub-base formation for road pavement was implemented by integrating a predictive model into a FORTRAN-based first-order reliability program so as to estimate RI values for all the compositional variables. Specific gravity (Gs) show the most significant influence among all the compositional parameters followed by sand content(Sa) and then Iron ore tailing (IOT) and Lime(Li) content on MDD. In the case of OMC, specific gravity (Gs), iron ore tailing content (IOT), lime content ( $\mathrm{Li}$ ) and Sand content $(\mathrm{Sa})$ compositional variables show high significant influence consecutively, on OMC. Although the beta values for all compositional values show significant influence on MDD and OMC, however, the safety index produced fall short of 1.0 as stated by the NKP for serviceability limit state design. From the results of reliability analysis, it could be observed that IOT and lime content has effect on both the MDD and OMC which could be related to the reaction mechanism initiated by the molding water content of compaction. This possibly could describe the variation of compaction characteristics due to the amount of IOT and lime content in the soil. It is thus important that caution on control of these variables is relevant in the course of field compaction specification and regulation in order to achieve a long lasting pavement. Finally, higher compactive efforts is suggested to model compaction characteristics of Li-IOT treated black cotton soil to achieve robust safety index.

\section{References}

[1] Köhler J. (2007) Reliability of Timber Structures, Unpublished Ph.D Thesis. Institute of Structural Engineering, Swiss Federal Institute of Technology, Zurich Switzerland.

[2] Clarke AB, Coverman, S.H. (1987) Structural Steelwork, limit State Design. J.W. Arrowsmith Ltd, Bristol, pp.59-62.

[3] Abubakar I, Ahmad IU (2007) Reliability Analysis of Steel Column Base Plates, Journal of Applied Sciences Research, 3(3):189-194.

[4] Moghal, AAB, Chittoori BCS, Basha, BM (2016) Effect of fibre reinforcement on CBR behavior of lime-blended expansive soils; reliability approach. Road Material and Pavement Design, http://dx.doi.org/10.1080/14680629.2016.1272497

[5] Osinubi KJ, Eberemu AO, Yohama, P, Etim, RK (2016) Reliability estimate of compaction characteristics of iron ore tailings treated tropical black clay as road pavement sub-base material, American society of Civil Engineering, Geotechnical Special publication, 271, pp 855-864. http://dx.doi.org/10.1061/9780784480144.085

[6] Sani, JE, Yohanna P, Etim KR, Osinubi JK, Eberemu, OA (2017) Reliability Evaluation of Optimum Moisture Content of Tropical Black Clay Treated with Locust Bean Waste Ash as Road Pavement Sub-base Material, Geotechnical and Geological Engineering 35:2421-2431, 2017. http://link.springer.com/article/10.1007/s10706-017-0256-2

[7] Etim, RK, Yohanna P, Attah IC, Eberemu AO (2018) Reliability-Based Evaluation of Compaction Characteristics of Periwinkle Shell Ash Treated Lateritic soil as Road Pavement Subbase Materials, Proceedings of 2018 NBBRI International Conference, Theme: Sustainable Development Goal (SDGs) and the Nigerian Construction Industry-Challenges and the way forward. NAF Conference Centre, Abuja, 12-14 ${ }^{\text {th }}$ June 2018, pp. 408-420.

[8] Yang, J, - DeWolf, J.T. (2002) Reliability Assessment of Highway Truss Sign Supports, Journal of Structural Engineering, 128(11): 1429. https://doi.org/10.1061/(ASCE)0733-9445(2002)128:11(1429)
[9] Afolayan, J.O, - Nwaiwu. C.M.O. (2005) Reliability-Based Assessment of Compacted Lateritic Soil Liners, Journal of Computers and Geotechnics, Elsevier publishers, 2(7): 505-519.

[10] Oriola, F, - Moses, G (2011) Compacted Black Cotton Soil Treated with Cement Kiln Dust as Hydraulic Barrier Material, AJSIR, 2(4):521-530.

[11] Chen FH (1988) Foundation on Expansive Soils. Elsevier Scientific Publication Company, Amsterdam.

[12] Warren KW, Kirby TM (2004) Expansive Clay soil: A Widespread and Costly Geohazard, Geostrata, Geo-Institute of the American Society Civil Engineers, Jan pp. 24-28.

[13] Ola SA (1983) The Geotechnical Properties of Black Cotton Soils of North Eastern Nigeria, In S. A. Ola (ed.) Tropical Soils of Nigeria in Engineering Practice. Balkama, Rotterdam, pp. 160-178.

[14] Etim RK, Attah IC, Ekpo DU, Usanga IN (2021) Evaluation on Stabilization Role of Lime and Cement in Expansive Black Clay-Oyster Shell Ash Composite. Transportation Infrastructure Geotechnology. https://doi.org/10.1007/s40515-021-00196-1

[15] JCSS (2001) Joint Committee for Structural Safety, Probabilistic Model Code", 2001 http://www.jcss.ethz.ch/

[16] Babu GLS, Basha BM (2008) Optimum design of cantilever retaining walls using target reliability approach, International Journal of Geomechanics, 8(4):240-252.

[17] Holický M (2013) Introduction to Probability and Statistics for Engineers, Springer, Heidelberg, New York, London.

[18] Holický M (2018) Target reliability of civil engineering structures, IOP Conf. Series: Materials Science and Engineering, 365, 052002 https://doi.org/10.1088/1757-899X/365/5/052002

[19] Chou YT (1990) Reliability design procedures for flexible pavements, Journal of Transportation Engineering, 116(5):602-614.

[20] Chua KH, Kiuredhian AD, Monismith CL (1992) Stochastic model for pavement design, Journal of Transportation Engineering, 118(6):769-786.

[21] Kenis W, Wang W (1998) Pavement variability and reliability, International symposium on heavy vehicle weights and dimensions, Maroochydore, Queensland, Australia, Part 3, 1998, pp. 213-231.

[22] Kim HB, Buch N (2003) Reliability-based pavement design model accounting for inherent variability of design parameters, Transportation Research Board, 82nd Annual Meeting, Washington DC.

[23] Halim IS, Tang, WH (1991) Reliability of Undrained Clay Slope Considering Geologic Anomaly, Proceedings of 6th International. Conference on Application of Statistics and Probability in Soil and Structural. Engineering, Mexico City Mexico, 776-783.

[24] Basha BM, Babu GLS (2009) Seismic reliability assessment of external stability of reinforced soil walls using pseudo-dynamic method, Geosynthetics International, 16(3): 197-215.

[25] Basha BM, Babu, GLS (2010) Optimum design for external seismic stability of geosynthetic reinforced soil walls: reliability based approach, Journal of Geotechnical and Geoenvironmental Engineering, 136(6):797-812.

[26] Kotegoda M, Rosso R (1997) Statistics, Probability, and Reliability for Civil and Environmental Engineers," New York, McGraw-Hill.

[27] Sani JE, Bello AO, Nwadiogbu CP (2014) Reliability estimate of strength characteristics of black cotton soil pavement sub-base stabilized with bagasse ash and cement kiln dust," Civil and Environmental Research, 6(11):115-135

[28] Afolayan JO, Abubakar I (2003) Reliability Analysis of Reinforced Concrete One-Way Slabs. The Ultimate Conditions, Nigerian Journal of Engineering, 11(2):28-31.

[29] Divinsky M, Ishai I, Livneh M (1996) Simplified generalized California Bearing Ratio pavement design equation, Transportation Research Record 1539, Transportation Research Board, National Research Council, Washington, DC, 44-50.

[30] Duncan MJ (2000) Factors of Safety and Reliability in Geotechnical Engineering, Journal of Geotechnical Geoenenviromental Engineering, ASCE, 126:307-316.

[31] Buki, JM (2016) Lime - Iron Ore Tailing Modification of Black Cotton Soil. Unpublished M.Sc. Thesis, Dept. of Civil Engineering, Ahmadu Bello University, Zaria, Kaduna State, 2016. 
[32] Osinubi KJ, Yohanna P, Eberemu AO (2015) Cement Modification of Tropical Black Clay Using Iron Ore Tailing as Admixture, Journal of Transportation Geotechnics, 5:35-49. 2015.

http://dx.doi.org/10.1016/j.trgeo.2015.10.001

[33] Etim RK, Eberemu AO, Osinubi KJ (2017) Stabilization of black cotton soil with lime and iron ore tailings admixture, Journal of Transportation Geotechnics Elsevier, 10:85-95.

http://dx.doi.org/10.1016/j.trgeo.2017.01.002

[34] Moses G, Etim RK, Sani JE, Nwude M (2018) Desiccation effect of compacted tropical black clay treated with concrete waste, Leonardo Electronic Journal of Practices and Technologies, 33:69-88.

[35] Moses G, Etim RK, Sani JE, Nwude M (2019) Desiccation-Induced Volumetric Shrinkage Characteristics of Highly Expansive Tropical Black Clay Treated with Groundnut Shell Ash for Barrier Consideration, Civil and Environmental Research, 11(8):58-74.

[36] Etim RK, Ekpo, DU, Attah, IC, Onyelowe KC. (2021) Effect of micro sized quarry dust particle on the compaction and strength properties of cement stabilized lateritic soil. Cleaner Materials.

https://doi.org/10.1016/j.clema.2021.100023

[37] Attah IC, Etim RK, Yohanna P, Usanga, IN. (2021) Understanding the effect of compaction energies on the strength indices and durability of oyster shell ash-lateritic soil mixtures for use in road works. Engineering and Applied Science Research. 48(2):151-160.

https://doi.org/10.14456/easr.2021.17

[38] Etim, RK, Ekpo DU, Ebong UB, Usanga IN. (2021) Influence of periwinkle shell ash on the strength properties of cement-stabilized lateritic soil. Int J. of Pavement Research Technology,

https://doi.org/10.1007/s42947-021-00072-8

[39] NKB (1978) NKB- Report No. 36. Recommendation for loading and safety regulations for structural design. Nordic Committee on Building Regulation.

[40]JCSS (1996) Joint Committee on Structural Safety. Background Documentation Eurocode 1 ENV, Part 1: Basis of Design, ECCS, Report No 94 .

$\underline{\text { Ref.: }}$

Yohanna, Paul - Etim, Roland K. - Ijimdiya, Thomas S. - Osinubi, Kolawole J. - Buki, John M.: Reliability analysis of compaction characteristics of tropical black clay admixed with lime and iron oresilica based dominant tailing

Építőanyag - Journal of Silicate Based and Composite Materials, Vol. 74, No. 1 (2022), 13-20. p.

https://doi.org/10.14382/epitoanyag-jsbcm.2022.3

\section{$3^{\text {rd }}$ ADVANCED}
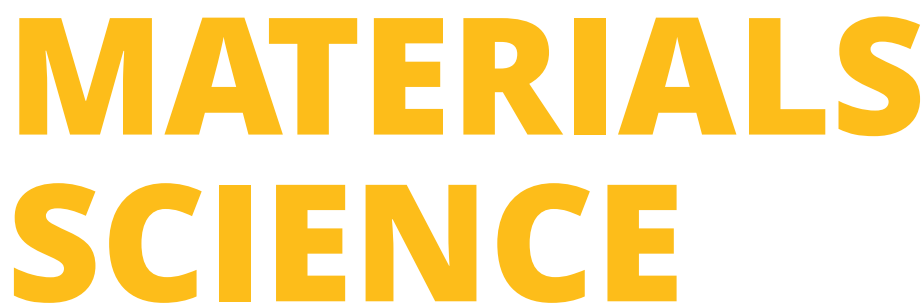

WOr
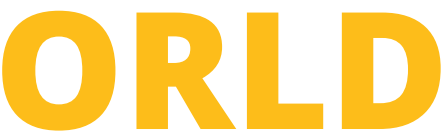

$\longrightarrow$
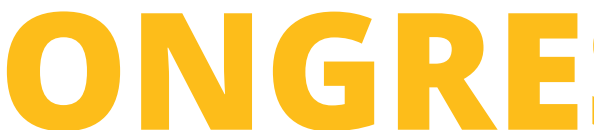

\section{MARCH 21-22, 2022}

LONDON, UK

\section{Theme}

"Anticipating Future Trends, New

Insights, and Cutting-Edge Technologies in Materials Science andEngineering "

http://advanced-

materialsscience.peersalleyconferences.com/
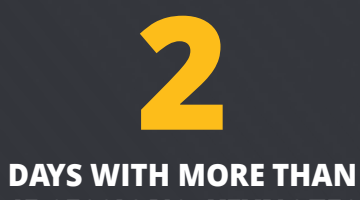

45 SESSIONS, KEYNOTES \& TALKS

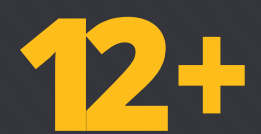

INNOVATIVE FEATURED SPEAKERS

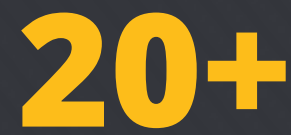

HOURS OF NETWORKING EVENTS

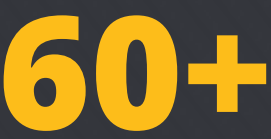

INTERNATIONAL SPEAKERS

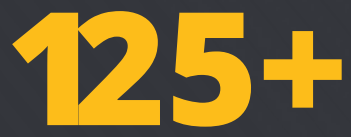

EDUCATIONAL SESSIONS 